\title{
Burden and Transmission Risks of Viral Hepatitis in Southern Ethiopia: Evidence Needed for Prevention and Control Measures
}

\author{
Gizachew Beykaso 1,2 \\ Andargachew Mulu ${ }^{3}$ \\ Mirutse Giday' \\ Nega Berhe (D) \\ Markos Selamu (iD ${ }^{2}$ \\ Adane Mihret ${ }^{3}$ \\ Tilahun Teklehaymanot' \\ 'Department of Molecular Biology and \\ Immunology, Aklilu Lemma Institute of \\ Pathobiology, Addis Ababa University, \\ Addis Ababa, Ethiopia; ${ }^{2}$ Department of \\ Public Health, College of Medicine and \\ Health Sciences, Wachemo University, \\ Hossana, Ethiopia; ${ }^{3}$ Department of \\ Virology, Armauer Hansen Research \\ Institute, Addis Ababa, Ethiopia
}

Background: Hepatitis B virus (HBV) and hepatitis C virus (HCV) are significant causes of liver-associated morbidity and mortality for millions of people globally. Ethiopia is one of the viral hepatitis-endemic countries with no national strategy for surveillance and limited data. As such, this study aimed to investigated the extent and associated risk factors of HBV and HCV among community members in southern Ethiopia.

Methods: A community-based cross-sectional study was conducted from January 2020 to August 2020. A structured questionnaire was used to collect behavioral and sociodemographic data. Serum samples were collected and assayed for seromarkers of HBV (HBsAg, anti-HBc, and anti-HBs) and HCV (anti-HCV) using ELISAs. In HBsAg-positive samples, HBV DNA was further quantified using RT-PCR. Data were entered into EpiData 3.1 and analyzed using SPSS 21.0. Descriptive statistics and logistic regression analysis were employed.

Results: The study included 693 participants. Seromarkers for HBsAg, anti-HCV, anti-HBc, and anti-HBs were found to be $9.5 \%, 1.4 \%, 31.1 \%$, and $14.3 \%$, respectively. In $66 \mathrm{HBsAg}$ positives, 57 (86.4\%) had quantifiable HBV DNA. Prevalence of current HBV infection $\left(\mathrm{HBsAg}^{+}\right.$, anti- $\mathrm{HBc}^{+}$, anti-HBs ${ }^{-}$) and lifetime exposure (positive for either HBsAg or anti$\mathrm{HBc}$ ) to $\mathrm{HBV}$ were $8.7 \%$ and $31.9 \%$, respectively, and $63.1 \%$ of participants were vulnerable or had no evidence of prior $\mathrm{HBV}$ infection $\left(\mathrm{HBsAg}^{-}\right.$, anti- $\mathrm{HBc}^{-}$, anti-HBs $\left.{ }^{-}\right)$. On multivariate logistic regression analysis, multiple sexual contacts, family history of hepatitis infection, alcohol consumption, and khat chewing were significantly associated with HBV. The seroprevalence of HBV was relatively high in this study area.

Conclusion: This study showed high prevalence of HBV infection, but low prevalence of $\mathrm{HCV}$. This indicates that HBV is a major health problem in this community. Populationbased surveillance, care, and treatment, as well as behavioral change and education programs, should be enhanced to minimize risk exposure.

Keywords: community-based, HBV, HCV, seroprevalence, southern Ethiopia

\section{Introduction}

Hepatitis B virus (HBV) and hepatitis C virus (HCV) are a global public health challenge and account for a significant proportion of liver diseases, primarily cirrhosis and hepatocellular carcinoma. ${ }^{1-3}$ The status of HBV and HCV infections varies significantly from one part of the world to another and changes over time. ${ }^{4-7}$ The rate of $\mathrm{HBV}$ infection varies from high- ( $>8 \%$ infection rate) to intermediate$(2 \%-8 \%)$ and low-endemicity $(<2 \%)$ areas. ${ }^{8}$ Africa is one of the highly endemic areas, ${ }^{9}$ but some northern countries are classified as intermediate, with an average
Correspondence: Gizachew Beykaso Department of Public Health, College of Medicine and Health Sciences, Wachemo University, PO Box 667, Hossana,

Ethiopia

Tel +25I-9l-206-653I

Email gbeykaso88@gmail.com 
rate of about $7 \%,{ }^{10}$ whereas most regions of western and eastern Africa are highly endemic areas, with chronic infection rates of $7 \%-10 \%$, unlike sub-Saharan Africa, where prevalence is $5 \%-25 \%$, accounting for $26 \%$ of liver cancer cases and 19 per 1,000 deaths. ${ }^{1,8,11}$ Similarly, the endemicity of HCV infection varies much like that of HBV infection from high- ( $>5 \%$ infection rate), to intermediate- $(1.1 \%-5 \%)$, low- $(0.2-1 \%)$, and very low-endemicity areas $(<0.1 \%) .^{1,12,13}$ African countries, mainly sub-Saharan regions, have among the highest prevalence of $\mathrm{HCV}$ in the world - $1 \%-26 \%$. More than 28 million people are chronically infected with HCV in this continent, and it is difficult to speculate about current and future trends. ${ }^{3-5,14-16}$

Both HBV and HCV can be transmitted sexually, parenterally, and vertically from mother to child, ${ }^{7,17}$ most often by percutaneous or mucous membrane exposure to infectious body fluids; ${ }^{18,19}$ however, perinatal exposure to $\mathrm{HBV}$ is the most common mode of transmission in areas of medium-high endemicity. ${ }^{20}$ Exposure leading to the transmission of HBV and HCV include needlestick injuries, ${ }^{21,22}$ circumcisions, ${ }^{23,24}$ tattooing, ${ }^{25}$ piercing, ${ }^{25,26}$ intravenous drug use, ${ }^{27}$ sharp materials, ${ }^{28}$ transfusion of infected blood or blood products, ${ }^{29-31}$ unprotected sexual contact, $^{32,33}$ and hemodialysis. ${ }^{34}$ Infants born to HBV- or HCV-infected mothers ${ }^{17}$ and those with immunosuppressive chronic diseases like diabetes mellitus ${ }^{35}$ are also at highrisk of $\mathrm{HBV}$ or $\mathrm{HCV}$ infection. ${ }^{7}$ Behavioral factors like alcohol consumption, ${ }^{36}$ multiple sexual contacts, ${ }^{37}$ and khat chewing ${ }^{38,39}$ put people at increased risk of transmission.

Ethiopia is grouped among the viral hepatitis-endemic countries, with recent prevalence of $7.4 \% \mathrm{HBV}$ and $3.1 \%$ $\mathrm{HCV},{ }^{14}$ but the country lacks a national strategy for surveillance of prevention and control of viral hepatitis. ${ }^{40}$ Community-based seroepidemiological surveys are infrequent and do not show the current burden of the viruses. ${ }^{14,41,42}$ These infections also remained underdiagnosed and underreported due to limited data, despite their highly infectious nature. Most reports on these infections have been from institution-based studies on high-risk groups. $^{14,43,44}$

In Ethiopia, almost all reports are based on $\mathrm{HBsAg}$ testing, with less emphasis on anti-HBc, anti-HBs, HBV DNA, and anti-HCV for HCV, despite their clinical importance. Screening for HBV anti-HBc and anti-HBs is important to provide lifetime exposure and identify individuals vulnerableto $\mathrm{HBV}$ infection, respectively. ${ }^{45}$ Quantifying
HBV DNA in HBsAg-positive samples is also crucial to identify those viremic individuals requiring follow-up monitoring and treatment, ${ }^{46,47}$ which is important to reduce transmission through counseling on risk behaviors. $^{48}$ Assessing seromarkers of $\mathrm{HBV}$ and $\mathrm{HCV}$ infections at the community level is essential to develop strategies to reduce transmission. Therefore, this study aimed to investigat the seroprevalence and associated factors of HBV and HCV infections among the general population in southern Ethiopia.

\section{Methods}

\section{Study Setting and Period}

The study was conducted from January to August 2020 in three zonal districts of southern Ethiopia: Hadiya, Kambata, and Silte.

\section{Study Design}

This was a community-based cross-sectional study conducted to determine the seromarkers of HBV and HCV infection and identify transmission risks.

\section{Study Population, Sample Size, and Sampling Method}

Study participants were individuals aged $\geq 5$ years, residents of the study districts, and had volunteered to participate in the study. From the three zonal districts (Hadiya, Kambata, and Silte), nine woredas (three from each district), and 18 kebeles (two from each woreda) were selected randomly. The sample size was calculated with assumptions of pooled seroprevalence of HBV in community-based studies of $8,{ }^{14} 95 \%$ confidence, $3 \%$ margin of error, and design effect of 2 , and finally increased by $10 \%$ to account for such contingencies such as nonresponse and recording errors. This resulted in a minimum sample of 693. Based on these estimations, 278 individuals from Hadiya, 245 from Kambata, and 170 from Silte were selected by proportional allocation. Households from each of the selected kebeles were selected using systematic random sampling after calculating the $K^{\text {th }}$ value by dividing the total number of households by the sample size. From each selected household, one participant was randomly recruited using a lottery method for those who were at home when visited. Individuals who were critically ill and unable to give responses were excluded. 


\section{Data Collection}

A structured questionnaire was administered by face-toface interview during house visits to collect sociodemographic, cultural (behavioral), and relevant clinical data. Blood samples $(5 \mathrm{~mL})$ were collected from each of the study participants. Sera were separated and stored at $-70^{\circ} \mathrm{C}$ until screening for $\mathrm{HBV}$ seromarkers ( $\mathrm{HBsAg}$, anti-HBc, and anti-HBs), HBV DNA, and anti-HCV. Screening for seromarkers HBsAg and anti-HCV was undertaken using HbsAg and anti-HCV ELISA kits (Wantai Biological) as per manufacturer instructions. Sensitivity and specificity of the HBsAg kit were $100 \%$ and $99.4 \%$ and for the anti-HCV kit $99 \%$ and $97 \%$, respectively. Anti-HBc and anti-HBs screening tests were also performed using ELISA kits (Monolisa anti-HBc Plus, Monolisa anti-HBs Plus, BioRad). Reactive samples were retested twice more and considered reactive if at least one of the two repetitions also gave a positive result. Samples found positive on HBsAg ELISA assays were further tested using quantitative PCR assays for detection and quantification of viral nucleic acid.

\section{HBV DNA Quantification}

Detection of HBV DNA was performed for all blood samples testing positive for HBsAg. HBV DNA was extracted from $200 \mu \mathrm{L}$ plasma using an m2000sp (Abbott Laboratories, Abbott Park, IL, USA), an automated sample-preparation system designed to use magnetic microparticle-based reagents for the purification of nucleic acids from samples, following the manufacturer's instructions. An internal control DNA was introduced into the sample-preparation procedure and processed along with the calibrators, controls, and samples. The occurrence of amplified HBV DNA and internal control was noticed during the extension and annealing step. The amplification cycle at which a normalized fluorescent signal was detected by the m2000rt was proportional to the log of the HBV DNA concentration present in the original sample. Each sample was then quantified by an external calibration curve.

\section{HBV DNA}

The concentration of HBV DNA in a sample and/or control was measured from either a stored calibration curve or a curve formed by calibrators in a calibration or sample run. The m2000rt spontaneously reports the results on its workstation. Assay results are reported in $\mathrm{IU} / \mathrm{mL}$ which is proportional to an average conversion factor of 3.41 ( $1 \mathrm{IU}=3.41$ copies).

\section{Quality Assurance}

Serum samples were stored at $-70^{\circ} \mathrm{C}$ until processed. The manufacturer's instructions and standard operating procedures were firmly followed during laboratory tests. ELISA results were determined based on the manufacturer's cutoff-value instruction. Negative, low-positive, and high-positiveinternal control kits were used with each run to check the quality of reagents according to the manufacturer's instructions.

\section{Data Processing and Analysis}

Data were processed, entered into EpiData 3.1, and analyzed using SPSS 21.0. Descriptive statistics - means \pm SD for continuous variables and frequencies for categorical variables - were employed. A binary logistic regression model was fitted to identify factors associated with the seroprevalence of HBV infection. Variables indicating significant associations on bivariate analysis were taken as candidates for multivariate analysis, and those showing significant associations on multivariate analysis were taken as final predictors of the dependent variable. These independent variables showing significant associations are reported using $P$-values, ORs, and $95 \%$ CIs. $P<0.05$ was determined to be statistically significant.

\section{Ethics Approval and Consent to Participate}

Ethics permission was obtained from the ethical review board of the Aklilu Lemma Institute of Pathobiology, Addis Ababa University. Written permission letters were submitted to all the administrative offices concerned. Informed consent was obtained from each participant after an explanation of the aim, potential risks, and importance of the study. Consent for participants aged $<18$ years was obtained from their parents or legal guardians. Participants were assured that they had the full right to take part or not to take part in the study. To maintain privacy, participants' information was coded and all personal identifiers removed. All methods were carried out in accordance with the Declaration of Helsinki and the National Research Ethics Review Guideline of Ethiopia.

\section{Results}

\section{Sociodemographic Characteristics of Participants}

A total of 693 (60.9\% female, age 6-82 years, mean age $31.74 \pm 9.32$ years) study participants were enrolled. Among these, 278 (40.1\%) were from Hadiya, 245 (35.4\%) from Kambata, and the remaining 170 (24.5\%) 
from Silte. Most (501, 72.3) were rural residents. A majority (58.8\%) were married (Table 1$)$.

\section{HBsAg and HBV DNA Positivity}

The seroprevalence of HBV infection (HBsAg ELISA) was 66 of $693(9.5 \%)$. Of the HBsAg-seropositive samples, 57 of $66(86.4 \%)$ were HBV nucleic acid-test positives or viremic $\mathrm{HBV}$-infected. The highest prevalence of HBV was observed in those aged $<18$ years $(12.4 \%)$, urban residents $(12.5 \%)$, and families with more than five members (11.3\%; Table 1). All HBV DNA-positive samples $(86.4 \%)$ were above the cutoff for detectable viral load $(200 \mathrm{IU} / \mathrm{mL})$ for HBV infection. Among participants with a family history of hepatitis infection $(n=63)$, those with multiple sexual contacts $(n=51)$, history of khat chewing $(\mathrm{n}=91)$, and history of alcohol consumption $(\mathrm{n}=74)$, the prevalence of $\mathrm{HBV}$ was $17.5 \%, 17.6 \%$, $16.5 \%$, and $14.9 \%$, respectively (Table 3 ).

\section{Seroprevalence of HCV Infections}

The overall seroprevalence of $\mathrm{HCV}$ infection was ten of $693(1.4 \%)$ using the anti-HCV ELISA. No participants

Table I Distribution of HBsAg, HBV DNA, and Anti-HCV Positivity with Sociodemographic Characteristics

\begin{tabular}{|c|c|c|c|c|c|}
\hline & & n (\%) & $\mathrm{HBsAg}^{+}, \mathrm{n}(\%)$ & HBV DNA ${ }^{+}, \mathrm{n}(\%)$ & anti-HCV ${ }^{+}$, $(\%)$ \\
\hline \multirow[t]{2}{*}{ Sex } & Male & $271(39.1)$ & $19(7.1)$ & $13(4.8)$ & $3(1.1)$ \\
\hline & Female & $422(60.9)$ & 47 (II.I) & $44(10.2)$ & $7(1.7)$ \\
\hline \multirow[t]{5}{*}{ Age, years } & $<18$ & 81 (1I.7) & $10(12.4)$ & $7(8.6)$ & $\mathrm{I}(\mathrm{I} .2)$ \\
\hline & $18-29$ & $234(33.8)$ & $24(10.3)$ & $19(8.1)$ & $3(1.3)$ \\
\hline & $30-45$ & $278(40.1)$ & $25(9.0)$ & $21(7.6)$ & $5(1.8)$ \\
\hline & $46-65$ & $72(10.4)$ & $6(8.3)$ & $6(6.9)$ & I (I.4) \\
\hline & $>65$ & $28(4.0)$ & $2(7.1)$ & $2(7.1)$ & - \\
\hline \multirow[t]{2}{*}{ Residence } & Rural & $50 \mathrm{I}(72.3)$ & $42(8.3)$ & $37(7.4)$ & $6(1.2)$ \\
\hline & Urban & $192(27.7)$ & $24(12.5)$ & $20(10.4)$ & $4(2.1)$ \\
\hline \multirow[t]{4}{*}{ Religion } & Protestant & $305(44.0)$ & $29(9.5)$ & $25(8.2)$ & $4(1.3)$ \\
\hline & Muslim & $193(27.8)$ & $24(12.4)$ & 22 (1 I.4) & $4(2.1)$ \\
\hline & Orthodox & $105(15.2)$ & $8(7.6)$ & $6(5.7)$ & I (I.0) \\
\hline & Catholic & $90(13.0)$ & $5(5.6)$ & $4(4.4)$ & I (I.7) \\
\hline \multirow[t]{4}{*}{ Education } & Illiterate & $233(33.6)$ & $25(10.7)$ & $21(9.0)$ & $3(1.3)$ \\
\hline & I-8 years & $201(29.0)$ & $19(9.4)$ & $16(8.0)$ & $2(1.0)$ \\
\hline & $9-12$ years & I $83(26.4)$ & $16(8.2)$ & $15(8.2)$ & $4(2.2)$ \\
\hline & University or above & 76 (II.0) & $5(6.6)$ & $5(6.6)$ & $\mathrm{I}(\mathrm{I} .3)$ \\
\hline \multirow[t]{4}{*}{ Marital status } & Married & 408 (58.9) & $42(10.3)$ & $36(8.8)$ & $7(1.7)$ \\
\hline & Single & $230(33.2)$ & $18(7.8)$ & $16(7.0)$ & $3(1.2)$ \\
\hline & Divorced & $23(3.3)$ & $3(13.0)$ & $3(13.0)$ & 一 \\
\hline & Widowed & $32(4.6)$ & $3(9.4)$ & $2(6.3)$ & - \\
\hline \multirow[t]{5}{*}{ Occupation } & Farmer & 360 (51.9) & $36(10.0)$ & $30(8.3)$ & $5(1.4)$ \\
\hline & Merchant & 79 (II.4) & $9(11.4)$ & 7 (8.7) & $2(2.5)$ \\
\hline & Laborer & $92(13.3)$ & $9(9.8)$ & $9(9.8)$ & I (I.I) \\
\hline & Student & $87(12.6)$ & $6(8.0)$ & $6(8.0)$ & 一 \\
\hline & Unemployed & $75(10.8)$ & $6(9.1)$ & $5(6.7)$ & $2(2.67)$ \\
\hline \multirow[t]{4}{*}{ Family size } & $<2$ & $48(6.9)$ & $3(6.3)$ & $3(6.3)$ & - \\
\hline & $2-3$ & $99(14.3)$ & $8(8.1)$ & $7(7.1)$ & I (I.0) \\
\hline & $4-5$ & $263(38.0)$ & $24(9.1)$ & $21(8.0)$ & $3(1.1)$ \\
\hline & $>5$ & $283(40.8)$ & 31 (II.3) & $26(9.2)$ & $6(2.1)$ \\
\hline \multirow[t]{3}{*}{ District } & Hadiya & $278(40.1)$ & $25(9.0)$ & $21(7.6)$ & $3(1.1)$ \\
\hline & Kambata & $245(35.4)$ & $19(7.8)$ & $17(6.9)$ & $2(0.8)$ \\
\hline & Silte & I 70 (24.5) & $22(12.9)$ & $19(11.2)$ & $5(2.9)$ \\
\hline
\end{tabular}


were infected with both HBV and HCV. Participants with multiple sexual contacts $(n=51)$, a family history of hepatitis infection $(n=63)$, and a history of chat chewing $(n=91)$ and alcohol consumption $(n=74)$ showed the highest prevalence of $\mathrm{HCV}: 5.9 \%, 4.8 \%, 4.3 \%$, and $3.9 \%$, respectively (Table 3).

\section{Seromarkers of HBV}

The HBsAg, anti-HBc, and anti-HBs seromarkers were found in $66(9.5 \%), 215(31.1 \%)$, and $99(14.3 \%)$ participants, respectively. The prevalence of current $\mathrm{HBV}$ infection $\left(\mathrm{HBsAg}^{+}\right.$, anti-HBc ${ }^{+}$, and anti-HBs${ }^{-}$) was 60 (8.7\%), while lifetime exposure (positive for either $\mathrm{HBsAg}$ or anti-HBc) to HBV was 221 (31.9\%). Participants vulnerable to HBV infection $\left(\mathrm{HBsAg}^{-}\right.$, anti-HBc ${ }^{-}$, anti-HBs ${ }^{-}$) numbered 437 (63.1\%). Those with immunity due to previous hepatitis $\mathrm{B}$ exposure $\left(\mathrm{HBsAg}^{-}\right.$, anti- $\mathrm{HBc}^{+}$, and anti- $\mathrm{HBs}^{+}$) and vaccination $\left(\mathrm{HBsAg}^{-}\right.$, anti-HBc ${ }^{-}$, anti-HBs ${ }^{+}$) numbered 64 (9.2\%) and 35 $(5.1 \%)$, respectively (Table 2$)$.

\section{Independent Predictors of HBV Infection}

On bivariate analysis, $\mathrm{HBV}$ infection was significantly $(P<0.05)$ associated with unprotected multiple sexual contact (COR 2.2, 95\% CI 1.9-18.3), alcohol consumption (COR 1.8, 95\% CI 3.1-20.2), contact with known hepatitis (jaundiced)

Table 2 HBV-seromarker Distribution

\begin{tabular}{|c|c|c|}
\hline & n (\%) & Interpretation \\
\hline $\begin{array}{l}\mathrm{HBsAg}^{-} \text {, anti-HB } \\
\mathrm{c}^{-} \text {, anti-HBs }\end{array}$ & $437(63.1)$ & $\begin{array}{l}\text { Vulnerable/no evidence of prior } \\
\text { infection }\end{array}$ \\
\hline $\begin{array}{l}\mathrm{HBsAg}^{-} \text {, anti-HBc } \\
\text { anti-HBs }\end{array}$ & $64(9.2)$ & $\begin{array}{l}\text { Immune due to past or natural } \\
\text { infection }\end{array}$ \\
\hline $\begin{array}{l}\mathrm{HBsAg}^{+}, \text {anti- } \mathrm{HBc}^{+}, \\
\text {anti-HB }\end{array}$ & $60(8.7)$ & $\begin{array}{l}\text { Chronically infected based on } \\
\text { anti-HBc total (Current infection) }\end{array}$ \\
\hline $\begin{array}{l}\mathrm{HBsAg}-\text {, anti-HB } \\
c^{-} \text {, anti-HBs }\end{array}$ & $35(5.1)$ & $\begin{array}{l}\text { Immune due to hepatitis } \\
\text { B vaccination }\end{array}$ \\
\hline $\begin{array}{l}\mathrm{HBsAg}^{+}, \text {anti-HB } \\
\mathrm{c}^{-} \text {, anti-HBs }\end{array}$ & $6(0.9)$ & $\begin{array}{l}\text { I. Early infection/low anti-HBc } \\
\text { level } \\
\text { 2. False-positive } \mathrm{HBsAg} \text {, thus } \\
\text { susceptible }\end{array}$ \\
\hline $\begin{array}{l}\mathrm{HBsAg}^{-} \text {, anti- } \mathrm{HBc}^{+} \\
\text {anti-HBs }\end{array}$ & $91(13.1)$ & $\begin{array}{l}\text { Unspecified - four options: } \\
\text { I. Resolved infection (common) } \\
\text { 2. False-positive anti-HBc, thus } \\
\text { susceptible } \\
\text { 3. "Low level" chronic infection } \\
\text { 4. Resolving acute infection }\end{array}$ \\
\hline
\end{tabular}

patients (COR 1.6, 95\% CI 7.8-54.1), family history of hepatitis infection (COR 2.2, 95\% CI 1.5-8.9), and khat chewing (COR 2.1, 95\% CI 1.2-9.2; Table 3). After adjustment for possible confounders with multivariate logistic regression analysis to explore independent predictors of $\mathrm{HBV}$ infection, multiple sexual contacts (AOR 3.9, 95\% CI 12.3-21.4), alcohol consumption (AOR 2.7, 95\% CI 6.7-19.8), khat chewing (AOR 3.2, 95\% CI 13.6-21.7), and family history of hepatitis (AOR 5.2, 95\% CI 1.6-11.2) were significantly associated with HBV infection (Table 3). Logistic regression analysis for $\mathrm{HCV}$ infection was not performed because we found only a small (ten) number of positive cases.

\section{Discussion}

In this study, we found a high rate $(9.5 \%)$ of $\mathrm{HBV}$ infection, showing high endemicity according to WHO criteria $(\geq 8 \%)^{8,49}$ Observed seroprevalence was higher than the previous national pooled prevalence of $7.4 \%$ and subgroup metaanalysis prevalence of $8.0 \%$ in community-based studies in Ethiopia. ${ }^{14}$ It is also higher than community-based study findings elsewhere in Ethiopia and eastern African countries, eg, $3.1 \%$ reported from Gojjam, northwest Ethiopia, ${ }^{41} 6.9 \%$ in Madagascar, $^{50} 2.1 \%$ in Kenya, ${ }^{51}$ as well as $6.1 \%$ in the whole African region ${ }^{52}$ and $3.5 \%$ global prevalence; ${ }^{53}$ however, significant heterogeneity among these studies was observed. The widest differences between Ethiopia and the others could be due to the use of different generations of test kits with different sensitivity and specificity, in addition to differences in study design, population, occupations, and geographical factors. This relative increase in the prevalence of $\mathrm{HBV}$ in the area compared to other regions suggests the current study district is a focal point for the prevention and control of hepatitis in Ethiopia. In addition, of those HBV-seropositive, the presence of high quantifiable plasma HBV DNA indicates there is a high proportion of viremic individuals in the community with relatively increased risk of $\mathrm{HBV}$ transmission and progression to chronic liver problems. Therefore, this needs prompt surveillance strategies for prevention and control, as well as screening for care and treatments.

On the other hand, this study revealed much higher findings than previous studies conducted in more developed regions, eg, $1.6 \%$ in Europe, ${ }^{54} 2.5 \%$ in South Korea, ${ }^{55} 2.8 \%$ in Turkey, ${ }^{56}$ and $1.4 \%$ in Brazil. ${ }^{57}$ Compared with these countries, the magnitude of HBV is considerably high. The varied differences between this study and the others might be due to differences in study duration and study settings that could affect social behavior, lifestyle, and socioeconomic status that predispose to HBV infection. ${ }^{16}$ In addition, individuals in more 
Table $3 \mathrm{HCV}$ and HBV Seroprevalence in Relation to Risk Factors

\begin{tabular}{|c|c|c|c|c|c|c|c|c|}
\hline & \multicolumn{2}{|c|}{ HCV } & \multicolumn{6}{|c|}{ HBV } \\
\hline & $\mathbf{P}(\%)$ & $\mathbf{n}$ & P (\%) & $\mathbf{n}$ & COR $(95 \% \mathrm{Cl})$ & $P$ & AOR $(95 \% \mathrm{Cl})$ & $P$ \\
\hline $\begin{array}{l}\text { Hospital admission } \\
\text { (yes) } \\
\text { No }\end{array}$ & $\begin{array}{l}2(3.9) \\
8(1.2)\end{array}$ & $\begin{array}{l}49 \\
634\end{array}$ & $\begin{array}{l}7(13.7) \\
59(8.9)\end{array}$ & $\begin{array}{l}44 \\
583\end{array}$ & $\begin{array}{l}\text { I.6 (I.4-19.4) } \\
\mathrm{I}\end{array}$ & 0.047 & $\begin{array}{l}2.6(0.5,23.8) \\
\text { I }\end{array}$ & 0.091 \\
\hline $\begin{array}{l}\text { Multiple sexual contacts } \\
\text { (yes) } \\
\text { No }\end{array}$ & $\begin{array}{l}3(5.9) \\
7(1.1)\end{array}$ & $\begin{array}{l}48 \\
635\end{array}$ & $\begin{array}{l}9(17.6) \\
57(8.9)\end{array}$ & $\begin{array}{l}42 \\
585\end{array}$ & $\begin{array}{l}2.2(1.9,18.3) \\
1\end{array}$ & 0.025 & $\begin{array}{l}3.9(12.3,21.4)^{*} \\
\text { । }\end{array}$ & 0.001 \\
\hline $\begin{array}{l}\text { Alcohol consumption } \\
\text { (yes) } \\
\text { No }\end{array}$ & $\begin{array}{l}3(3.9) \\
7(1.1)\end{array}$ & $\begin{array}{l}75 \\
608\end{array}$ & $\begin{array}{l}11(14.9) \\
55(8.9)\end{array}$ & $\begin{array}{l}63 \\
564\end{array}$ & $\begin{array}{l}1.8(3.1,20.2) \\
1\end{array}$ & 0.018 & $\begin{array}{l}2.7(6.7,19.8)^{*} \\
\text { I }\end{array}$ & 0.006 \\
\hline $\begin{array}{l}\text { Intravenous drug use } \\
\text { (yes) } \\
\text { No }\end{array}$ & $\begin{array}{l}3(3.3) \\
7(1.1)\end{array}$ & $\begin{array}{l}90 \\
593\end{array}$ & $\begin{array}{l}\text { II (II.8) } \\
55(9.2)\end{array}$ & $\begin{array}{l}82 \\
545\end{array}$ & $\begin{array}{l}\text { I.3 }(3.4,26.4) \\
\text { I }\end{array}$ & 0.044 & $\begin{array}{l}1.9(0.6,17.4) \\
\text { I }\end{array}$ & 0.056 \\
\hline $\begin{array}{l}\text { Tooth extraction } \\
\text { (yes) } \\
\text { No }\end{array}$ & $\begin{array}{l}4(4.3) \\
6(1.0)\end{array}$ & $\begin{array}{l}85 \\
598\end{array}$ & $\begin{array}{l}5(11.4) \\
61(9.6)\end{array}$ & $\begin{array}{l}39 \\
587\end{array}$ & $\begin{array}{l}1.2(9.6,22.4) \\
1\end{array}$ & 0.011 & I.4 (4.7, 19.6)| & 0.075 \\
\hline $\begin{array}{l}\text { Surgical procedure } \\
\text { (yes) } \\
\text { No }\end{array}$ & $\begin{array}{l}2(4.3) \\
8(1.2)\end{array}$ & $\begin{array}{l}45 \\
638\end{array}$ & $\begin{array}{l}5(8.6) \\
61(9.6)\end{array}$ & $\begin{array}{l}50 \\
577\end{array}$ & $\begin{array}{l}0.9(0.8,12.5) \\
1\end{array}$ & 0.045 & $\begin{array}{l}3.3(15.1,32.4) \\
1\end{array}$ & 0.092 \\
\hline $\begin{array}{l}\text { Contact with jaundiced or hepatitis patients } \\
\text { (yes) } \\
\text { No }\end{array}$ & $\begin{array}{l}2(3.9) \\
8(1.2)\end{array}$ & $\begin{array}{l}56 \\
627\end{array}$ & $\begin{array}{l}12(13.8) \\
54(8.9)\end{array}$ & $\begin{array}{l}75 \\
552\end{array}$ & $\begin{array}{l}1.6(7.8,54.1) \\
\text { I }\end{array}$ & 0.039 & $\begin{array}{l}2.9(5.8,17.7) \\
1\end{array}$ & 0.003 \\
\hline $\begin{array}{l}\text { Family history of infection } \\
\text { (yes) } \\
\text { No }\end{array}$ & $\begin{array}{l}3(4.8) \\
7(1.1)\end{array}$ & $\begin{array}{l}60 \\
623\end{array}$ & $\begin{array}{l}\text { II (17.5) } \\
55(8.3)\end{array}$ & $\begin{array}{l}52 \\
575\end{array}$ & $\begin{array}{l}2.2(1.5,8.9) \\
1\end{array}$ & 0.048 & $\begin{array}{l}5.2(1.6,11.2)^{*} \\
1\end{array}$ & 0.001 \\
\hline $\begin{array}{l}\text { Khat^ chewing } \\
\text { (yes) } \\
\text { No }\end{array}$ & $\begin{array}{l}4(4.3) \\
6(1.0)\end{array}$ & $\begin{array}{l}67 \\
616\end{array}$ & $\begin{array}{l}15(16.5) \\
51(8.5)\end{array}$ & $\begin{array}{l}76 \\
551\end{array}$ & $\begin{array}{l}2.1(1.2,9.2) \\
1\end{array}$ & 0.032 & $\begin{array}{l}3.2(13.6,21.7)^{*} \\
\text { । }\end{array}$ & 0.009 \\
\hline $\begin{array}{l}\text { History of tattooing } \\
\text { (yes) } \\
\text { No }\end{array}$ & $\begin{array}{l}3(4.8) \\
7(1.1)\end{array}$ & $\begin{array}{l}72 \\
611\end{array}$ & $\begin{array}{l}5(11.9 \\
61(9.4)\end{array}$ & $\begin{array}{l}37 \\
590\end{array}$ & $\begin{array}{l}\text { I.3 }(1.6,5.7) \\
\text { । }\end{array}$ & 0.041 & $\begin{array}{l}0.8(0.9,31.7) \\
।\end{array}$ & 0.065 \\
\hline
\end{tabular}

Notes: ${ }^{* P}<0.05$. $P$, positive; $N$, negative; I, reference. ${ }^{\wedge}$ Khat is a plant native to Ethiopia. It contains the alkaloid cathinone, a stimulant that is said to cause excitement and euphoria.

advanced nations get proper vaccines and work in healthier clinical settings where their protection is reasonably maintained, and these factors might result in a reduced risk of HBV infection.

On the contrary, the overall seroprevalence of $\mathrm{HCV}$ in the study area was $1.4 \%$. This seroprevalence of anti-HCV is classified as low endemicity by WHO criteria, ${ }^{8,58,59}$ and agrees with similar studies in Ethiopia. ${ }^{41,60}$ It is also consistent with other studies from eastern Africa. ${ }^{61,62}$ On the contrary, the seroprevalence of anti-HCV reported in our study was less than that from pooled national prevalence of Ethiopia (3.1\%) ${ }^{14}$ and the 3.0\% reported in sub-Saharan Africa. ${ }^{63}$ This might be due to differences in study period, design, population, and occupation.

We found a higher rate of $\mathrm{HBV}$ infection in larger families than smaller ones. Several studies have shown and suggested similar findings. ${ }^{4,41,64}$ This higher rate of HBV infection in larger families could explain the presence of horizontal transmission of HBV infection within the family. In a large family, there might be increased close contact of family members that could create an increased chance of HBV transmission. We also found 
a higher rate of HBV infection in younger people than older ones. Some studies have shown and suggested similar findings. ${ }^{65,66}$ The probable reason for this difference could be that higher positivity in younger people being related to vertical transmission, and the highest chance of viral persistence to the progression of chronic HBV infection is in the early age of infection. This study likewise revealed high prevalence of $\mathrm{HBV}$ infection in less educated individuals, somewhat similar to other studies conducted in Ethiopia ${ }^{5,41,67,68}$ and elsewhere. This relatively higher HBV seropositivity among the less educated might be attributed to poor awareness regarding modes of transmission, and increased education might increase awareness of prevention practices.

Multivariate analysis controlling for potential confounders showed a significant association of family history of hepatitis infection, multiple sexual contacts, khat chewing, and alcohol consumption with seropositivity of HBsAg, which is consistent with other study findings from Ethiopia. ${ }^{20,69}$ In this study, participants who had a family history of hepatitis infection had a fivefold chance of acquiring HBV. This was an independent risk factor and is in line with a previous study from northwest Ethiopia ${ }^{70}$ and a study from Kenya. ${ }^{71}$ This could explain close contact of family members with hepatitis patients increasing the chance of HBV transmission in the family or family environments that need a contact-screening program and intervention. Participants who practiced sex with multiple sexual partners had higher odds of HBV infection than their counterparts, as demonstrated elsewhere in Africa. ${ }^{18,52,72}$ Alcohol drinkers had an almost threefold risk of being positive for HBsAg and anti-HCV compared to their counterparts, showing the influence of alcohol consumption in the transmission of viral hepatitis. ${ }^{15,73}$

\section{Strengths and Limitations}

The inclusion of a large sample size a wide population group covering rural and urban populations and the use of fourth-generation ELISA and HBV PCR to provide evidence for active viremia are the strengths of this study. However, this study has also some limitations, including a lack of HCV molecular nucleic acid testing, $\mathrm{HBeAg}$, and anti-HBc IgM tests to differentiate between active viral replication and acute infection; however, the evidence was provided by PCR for active viremia. This study also lacked an occult hepatitis B test in HBsAg ELISA negatives to estimate silent-transmission risks.

\section{Conclusion}

The findings of this study indicated that the magnitude of HBV infection among the general population was high, but low for HCV infection. A high proportion of the HBsAgpositive individuals were also HBV DNA-positive with high viral load indicating actively viremic HBV infection. Therefore, this high viremic HBV infection puts individuals at risk of developing chronic liver diseases, in addition to spreading HBV to others. A majority of participants were found to be susceptible to HBV infection. Modifiable risk factors, such as multiple sexual contacts, family history of hepatitis infection, alcohol consumption, and khat chewing, were identified. This indicates there are high risks of transmission of these infectious pathogens in the community and points to a need for special attention to be paid to HBV-linked risk factors. Therefore, there is a need for prompt action to emphasize efforts alleviating transmission through awareness creation on modes of transmission, vaccination, and early screening, and treatment policies must be strengthened to minimize and control the spread of infection.

\section{Data Sharing}

The data used to support the conclusions of this study are available upon reasonable request from the corresponding author.

\section{Acknowledgments}

We would like to thank Addis Ababa University, the School of Graduate Studies, and Aklilu Lemma Institute of Pathobiology for their support in this research. Our heartfelt gratitude also goes to the Southern Regional Blood Bank of Hossana and the Armauer Hansen Research Institute for their valuable logistic support, which was extremely important in achieving this research. Furthermore, we would like to thank the study participants.

\section{Author Contributions}

All authors significantly contributed to conceptualization and design, data acquisition, or data analysis and interpretation, contributed to the preparation of the manuscript or critical revision of the manuscript for substantial intellectual content, read and agreed to the final version for submission to this journal, and agree to be accountable for all aspects of the work. 


\section{Funding}

This study was funded by grants obtained by Addis Ababa University. The sponsor had no involvement in study conception, design, data processing, manuscript writing, or decision to publish.

\section{Disclosure}

The authors declare that they have no conflicts of interest in this work.

\section{References}

1. Abdel-Hady M, Kelly D. Chronic hepatitis B in children and adolescents: epidemiology and management. Ped Drugs. 2013;15 (4):311-317. doi:10.1007/s40272-013-0010-z

2. Abebe A, Nokes DJ, Dejene A, Enquselassie F, Messele T, Cutts FT. Seroepidemiology of hepatitis B virus in Addis Ababa, Ethiopia: transmission patterns and vaccine control. Epidemiol Infect. 2003;131(1):757-770.

3. Allain JP, Owusu-Ofori S, Bates I. Blood transfusion in sub-Saharan Africa. Transf Altern Transf Med. 2004;6(1):16-23.

4. Balew M, Moges F, Yismaw G, Unakal C. Assessment of hepatitis $\mathrm{B}$ virus and hepatitis $\mathrm{C}$ virus infections and associated risk factors in HIV infected patients at Debretabor hospital, South Gondar, Northwest Ethiopia. Asian Pac J Trop Dis. 2014;4(1):1-7.

5. Bane A, Patil A, Khatib M. Healthcare cost and access to care for viral hepatitis in Ethiopia. Int J Innov Appl Stud. 2014;9(4):1718.

6. Daw MA, Dau AA. Hepatitis C virus in Arab world: a state of concern. Sci World J. 2012;71:719494.

7. El-Serag HB. Epidemiology of viral hepatitis and hepatocellular carcinoma. Gastroenterology. 2012;142(6):1264-1273.

8. Lavanchy D. Hepatitis B virus epidemiology, disease burden, treatment, and current and emerging prevention and control measures. J Viral Hepat. 2004;11(2):97-107.

9. Schweitzer A, Horn J, Mikolajczyk RT, Krause G, Ott JJ. Estimations of worldwide prevalence of chronic hepatitis B virus infection: a systematic review of data published between 1965 and 2013. The Lancet. 2015;386(10003):1546-1555.

10. Lavanchy D, Kane M. Global Epidemiology of Hepatitis B Virus Infection, in Hepatitis B Virus in Human Diseases. Springer; 2016: 187-203.

11. Lok AS, McMahon BJ. Chronic hepatitis B. Hepatology. 2007;45(2): p. $507-539$.

12. Franco E, Bagnato B, Marino MG, Meleleo C, Serino L, Zaratti L. Hepatitis B: epidemiology and prevention in developing countries. World J Hepatol. 2012;4(3):74.

13. Hwang EW, Cheung R. Global epidemiology of hepatitis B virus (HBV) infection. N Am J Med Sci (Boston). 2011;4:1.

14. Belyhun Y, Maier M, Mulu A, Diro E, Liebert UG. Hepatitis viruses in Ethiopia: a systematic review and meta-analysis. BMC Infect Dis. 2016;16(1):1-4.

15. Betela B, Kemal F, Nigussu D. Prevalence of hepatitis B virus and related risk factors: a case study at Assela referral hospital, Oromia, Ethiopia. Int STD Res Rev. 2018;20:1-7.

16. Mühlberger N, Schwarzer R, Lettmeier B, Sroczynski G, Zeuzem S, Siebert U. HCV-related burden of disease in Europe: a systematic assessment of incidence, prevalence, morbidity, and mortality. $B M C$ Public Health. 2009;9(1):1-4.

17. Farshadpour F. Prevalence and predominant genotype of Hepatitis $\mathrm{C}$ virus infection and associated risk factors among pregnant women in Iran. Biomed Res Int. 2021. doi:10.1155/2021/9294276
18. Onwuakor CE, Eze VC, Nwankwo IU, Iwu JO. Sero-prevalence of hepatitis B surface antigen (HBsAg) amongst pregnant women attending antenatal clinic at the Federal Medical Centre Umuahia, Abia State, Nigeria. Am J Public Health Res. 2014;2(6):255-259.

19. Locarnini S, Hatzakis A, Chen DS, Lok A. Strategies to control hepatitis B: public policy, epidemiology, vaccine and drugs. J Hepatol. 2015;62(1):S76-86.

20. Tegegne D, Desta K, Tegbaru B, Tilahun T. Seroprevalence and transmission of Hepatitis $\mathrm{B}$ virus among delivering women and their new born in selected health facilities, Addis Ababa, Ethiopia: a cross sectional study. BMC Res Notes. 2014;7(1):1-7.

21. Himmelreich H, Rabenau HF, Rindermann M, et al. The management of needlestick injuries. Deutsches Ärzteblatt Int. 2013;110(5):61.

22. Kiyosawa K, Sodeyama T, Tanaka E, et al. Hepatitis C in hospital employees with needlestick injuries. Ann Intern Med. 1991;115 (5):367-369.

23. Medhat A, Shehata M, Magder LS, et al. Hepatitis c in a community in Upper Egypt: risk factors for infection. Am J Trop Med Hyg. 2002;66(5):633-638.

24. Mousa HA. Transmission of bloodborne infections by circumcision procedure. J Infect Dis Ther. 2015;3(3):e107.

25. Urbanus AT, Van Den Hoek A, Boonstra A, et al. People with multiple tattoos and/or piercings are not at increased risk for $\mathrm{HBV}$ or HCV in The Netherlands. PLoS One. 2011;6(9):e24736.

26. Yang S, Wang D, Zhang Y, et al. Transmission of hepatitis B and $\mathrm{C}$ virus infection through body piercing: a systematic review and meta-analysis. Medicine. 2015;94:47.

27. Farshadpour F. Lurking epidemic of hepatitis $\mathrm{C}$ virus infection in Iran: a call to action. World J Hepatol. 2017;9(24):1040-1042.

28. Bekele T, Gebremariam A, Kaso M, Ahmed K. Factors associated with occupational needle stick and sharps injuries among hospital healthcare workers in Bale Zone, Southeast Ethiopia. PLoS One. 2015;10(10):e0140382.

29. Allain JP, Mihaljevic I, Gonzalez-Fraile MI, et al. Infectivity of blood products from donors with occult hepatitis B virus infection. Transfusion. 2013;53(7):1405-1415.

30. Jayaraman S, Chalabi Z, Perel P, Guerriero C, Roberts I. The risk of transfusion-transmitted infections in sub-Saharan Africa. Transfusion. 2010;50(2):433-442.

31. Fessehaye N, Naik D, Fessehaye T. Transfusion transmitted infections-a retrospective analysis from the National Blood Transfusion Service in Eritrea. Pan Afr Med J. 2011;9:1.

32. Parvez F, Katyal M, Alper H, Leibowitz R, Venters H. Female sex workers incarcerated in New York City jails: prevalence of sexually transmitted infections and associated risk behaviors. Sex Transm Infect. 2013;89(4):280-284.

33. Shannon K, Rusch M, Morgan R, Oleson M, Kerr T, Tyndall MW. $\mathrm{HIV}$ and $\mathrm{HCV}$ prevalence and gender-specific risk profiles of crack cocaine smokers and dual users of injection drugs. Subst Use Misuse. 2008;43(3-4):521-534.

34. Gasim GI, Hamdan HZ, Hamdan SZ, Adam I. Epidemiology of hepatitis $\mathrm{B}$ and hepatitis $\mathrm{C}$ virus infections among hemodialysis patients in Khartoum, Sudan. J Med Virol. 2012;84(1):52-55.

35. Farshadpour F. Prevalence and genotype distribution of hepatitis $\mathrm{C}$ virus infection among patients with type 2 diabetes mellitus. Med Principles Pract. 2018;27(4):308-316.

36. Ribes J, Clèries R, Esteban L, Moreno V, Bosch FX. The influence of alcohol consumption and hepatitis $\mathrm{B}$ and $\mathrm{C}$ infections on the risk of liver cancer in Europe. J. J Hepatol. 2008;49(2):233-242.

37. Tohme RA, Holmberg SD. Is sexual contact a major mode of hepatitis C virus transmission? Hepatology. 2010;52(4):1497-1505.

38. Beykaso G, Teklehaymanot T, Giday M, et al. Estimating the transmission risks of viral hepatitis and HIV among blood donors in Hossana, Southern Ethiopia. Risk Manag Healthc Policy. $2021 ; 14: 3117$. 
39. Hebo HJ, Gemeda DH, Abdusemed. KA. Hepatitis B and C viral infection: prevalence, knowledge, attitude, practice, and occupational exposure among healthcare workers of Jimma University Medical Center, southwest Ethiopia. Sci World J. 2019;4:1-11.

40. Shiferaw F, Letebo M, Bane A. Chronic viral hepatitis: policy, regulation, and strategies for its control and elimination in Ethiopia. BMC Public Health. 2016;16(1):1-13.

41. Abera B, Adem Y, Yimer M, Mulu W, Zenebe Y, Mekonnen Z. Community seroprevalence of hepatitis $\mathrm{B}, \mathrm{C}$ and human immunodeficiency virus in adult population in gojjam zones, northwest Ethiopia. Virol J. 2017;14(1):1-5.

42. Gelaw B, Mengitsu Y. The prevalence of HBV, HCV and malaria parasites among blood donor in Amhara and Tigray regional states. Ethiop J Health Develop. 2008;22(1):3-7.

43. Abera B, Zenebe Y, Mulu W, Kibret M, Kahsu G. Seroprevalence of hepatitis $\mathrm{B}$ and $\mathrm{C}$ viruses and risk factors in HIV infected children at the Felgehiwot referral hospital, Ethiopia. BMC Res Notes. 2014;7 (1): $1-6$.

44. Hundie GB, Raj VS, GebreMichael D, Haagmans BL. Seroepidemiology of hepatitis B and C virus infections among blood donors in Ethiopia. J Med Virol. 2017;89(7):1300-1303.

45. Nishida T, Matsubara T, Yakushijin T, Inada M. Prediction and clinical implications of HBV reactivation in lymphoma patients with resolved HBV infection: focus on anti-HBs and anti-HBc antibody titers. Hepatol Int. 2019;13(4):407-415.

46. Negero A, Sisay Z, Medhin G. Prevalence of Hepatitis B surface antigen (HBsAg) among visitors of Shashemene General Hospital voluntary counseling and testing center. BMC Res Notes. 2011;4(1):1-5.

47. Ayana DA, Mulu A, Mihret A, Seyoum B, Aseffa A, Howe R. Hepatitis B virus seromarkers among HIV infected adults on ART: an unmet need for HBV screening in eastern Ethiopia. PLoS One. 2019;14(12):e0226922.

48. World Health Organization. WHO Guidelines on Hepatitis $B$ and $C$ Testing. World Health Organization; 2017.

49. Spearman CW, Afihene M, Ally R, et al. Hepatitis B in sub-Saharan Africa: strategies to achieve the 2030 elimination targets. Lancet Gastroenterol Hepatol. 2017;2(12):900-909.

50. Coccolini F, Catena F, Moore EE, et al. WSES classification and guidelines for liver trauma. World J Emerg Surg. 2016;11(1):1-8.

51. Ochwoto M, Kimotho JH, Oyugi J, et al. Hepatitis B infection is highly prevalent among patients presenting with jaundice in Kenya. BMC Infect Dis. 2016;16(1):1-4.

52. Cruz HM, Scalioni LD, Paula VS, et al. Poor sensitivity of rapid tests for the detection of antibodies to the hepatitis B virus: implications for field studies. Memórias Do Instituto Oswaldo Cruz. 2017;112:209-213.

53. Razavi H. Making the case for looking beyond WHO estimates for the global burden of hepatitis C and B. J Viral Hepat. 2016;23(7):576.

54. Hahné SJ, Veldhuijzen IK, Wiessing L, Lim TA, Salminen M, van de Laar M. Infection with hepatitis $\mathrm{B}$ and $\mathrm{C}$ virus in Europe: a systematic review of prevalence and cost-effectiveness of screening. BMC Infect Dis. 2013;13(1):1-6.

55. Kang J, Cho JH, Suh CW, et al. High prevalence of hepatitis B and hepatitis $\mathrm{C}$ virus infections in Korean patients with hematopoietic malignancies. Ann Hematol. 2011;90(2):159-164.

56. Köse Ş, Mandıracıoğlu A, Çavdar G, et al. Seroprevalence of hepatitis B and hepatitis C: a community based study conducted in Izmir, Turkey. Prevalence. 2014;45(7):8.

57. Scaraveli NG, Passos AM, Voigt AR, et al. Seroprevalence of hepatitis B and hepatitis C markers in adolescents in Southern Brazil. Cad Saude Publica. 2011;27:753-758.
58. World Health Organization. Combating Hepatitis $B$ and $C$ to Reach Elimination by 2030: Advocacy Brief. World Health Organization; 2016.

59. Te HS, Jensen DM. Epidemiology of hepatitis B and C viruses: a global overview. Clin Liver Dis. 2010;14(1):1-21.

60. Yazie TD, Tebeje MG. An updated systematic review and meta-analysis of the prevalence of hepatitis B virus in Ethiopia. BMC Infect Dis. 2019;19(1):1-3.

61. Chaabna K, Kouyoumjian SP, Abu-Raddad LJ. Hepatitis C virus epidemiology in Djibouti, Somalia, Sudan, and Yemen: systematic review and meta-analysis. PLoS One. 2016;11(2):e0149966.

62. Chaabna K, Mohamoud YA, Chemaitelly H, Mumtaz GR, AbuRaddad LJ. Protocol for a systematic review and meta-analysis of hepatitis $\mathrm{C}$ virus $(\mathrm{HCV})$ prevalence and incidence in the Horn of Africa sub-region of the Middle East and North Africa. Syst Rev. 2014;3(1):1-5.

63. Mapoure NY, Budzi MN, Eloumou SA, Malongue A, Okalla C, Luma HN. Neurological manifestations in chronic hepatitis C patients receiving care in a reference hospital in sub-Saharan Africa: a cross-sectional study. PLoS One. 2018;13(3):e0192406.

64. Biazin H, Teshome S, Ayenew Z, et al. Determining seroprevalence of hepatitis $\mathrm{B}$ and $\mathrm{C}$ virus infections and associated risk factors among apparently healthy mothers in Addis Ababa, Ethiopia. Ethiop Med J. 2019. doi:10.5772/intechopen. 99117

65. Desalegn Z, Wassie L, Beyene HB, Mihret A, Ebstie YA. Hepatitis $\mathrm{B}$ and human immunodeficiency virus co-infection among pregnant women in resource-limited high endemic setting, Addis Ababa, Ethiopia: implications for prevention and control measures. Eur J Med Res. 2016;21(1):1-7.

66. Ding Y, Sheng Q, Ma L, Dou X. Chronic HBV infection among pregnant women and their infants in Shenyang, China. Virol J. 2013;10(1):1-5.

67. Kebede W, Abdissa A, Seid Y, Mekonnen Z. Seroprevalence and risk factors of hepatitis B, hepatitis $\mathrm{C}$ and $\mathrm{HIV}$ infections among prisoners in Jimma Town, Southwest Ethiopia. Asian Pac J Trop Dis. 2017;7 (5):270-275

68. Mazengia A, Yismaw G, Anagaw B, Unakal C. Seroprevalence and associated risk factors of $\mathrm{HBV}$ and $\mathrm{HCV}$ among people attending the HIV VCT centre at Deber Markos Referral Hospital, Northwest Ethiopia. J Pharm Biomed Sci. 2013;30(30):1027-1034.

69. Umare A, Seyoum B, Gobena T, Haile Mariyam T. Hepatitis B virus infections and associated factors among pregnant women attending antenatal care clinic at Deder Hospital, Eastern Ethiopia. PLoS One. 2016;11(11):e0166936.

70. Molla S, Munshea A, Nibret E. Seroprevalence of hepatitis B surface antigen and anti HCV antibody and its associated risk factors among pregnant women attending maternity ward of Felege Hiwot Referral Hospital, northwest Ethiopia: a cross-sectional study. Virol J. 2015;12 (1):1-9.

71. Furuya-Kanamori L, Liang S, Milinovich G, et al. Co-distribution and co-infection of chikungunya and dengue viruses. BMC Infect Dis. 2016;16(1):1.

72. Loomba R, Rowley A, Wesley R, et al. Systematic review: the effect of preventive lamivudine on hepatitis B reactivation during chemotherapy. Ann Intern Med. 2008;148(7):519-528.

73. Betela B, Kemal F. Awareness about Hepatitis B and/or C Viruses among Residents of Adama and Assela Cities. Oromia Regional State, Oromia, Ethiopia. Asian $J$ Res Infect Dis. 2018:1-9. doi:10.9734/ajrid/2018/v1i113950 


\section{Publish your work in this journal}

Risk Management and Healthcare Policy is an international, peerreviewed, open access journal focusing on all aspects of public health, policy, and preventative measures to promote good health and improve morbidity and mortality in the population. The journal welcomes submitted papers covering original research, basic science, clinical \& epidemiological studies, reviews and evaluations, guidelines, expert opinion and commentary, case reports and extended reports. The manuscript management system is completely online and includes a very quick and fair peer-review system, which is all easy to use. Visit http://www.dovepress.com/testimonials.php to read real quotes from published authors.

Submit your manuscript here: https://www.dovepress.com/risk-management-and-healthcare-policy-journal 